\title{
REAKSI PASAR ATAS PENGUMUMAN DIVIDEN: SEBUAH TINJAUAN ULANG
}

\author{
Fransisca Astuti Mutiara K D ${ }^{1}$, Leo Indra Wardhana ${ }^{2 *}$ \\ ${ }^{1}$ Magister Manajemen Fakultas Ekonomika dan Bisnis, Universitas Gadjah Mada, Indonesia \\ ${ }^{2}$ Departemen Ekonomika dan Bisnis Sekolah Vokasi, Universitas Gadjah Mada, Indonesia \\ Laboratorium Akuntansi dan Bisnis, Sekolah Vokasi, Universitas Gadjah Mada, Indonesia \\ *Email corresponding author: leo.wardhana@ugm.ac.id \\ Received 09/09/2020 Direvisi 21/09/2020 Diterbitkan 30/09/2020
}

\begin{abstract}
Abstrak
Studi ini meninjau kembali reaksi pasar atas peristiwa pembayaran dividen, tanggal cumdividen, dan tanggal pembayaran menggunakan metode studi peristiwa. Sampel penelitian ini mencakup semua pengumuman dividen dari tahun 2017 hingga 2018 di Bursa Efek Indonesia. Penelitian ini melakukan berbagai uji statistik yang kuat yang diusulkan oleh Harrington dan Shrider (2007). Mereka menunjukkan bahwa uji-t klasik standar tidak cukup untuk memastikan pengembalian abnormal pada suatu peristiwa karena bias karena volatilitas yang disebabkan oleh suatu peristiwa. Menggunakan berbagai uji statistik untuk menguji abnormal return, penelitian ini menunjukkan bahwa pasar memang bereaksi terhadap tanggal cum-dividen dan tanggal pembayaran dividen, serta menunjukkan bahwa uji-t klasik menunjukkan kesimpulan yang sama dengan pengujian lainnya. Dengan demikian, penelitian ini memvalidasi penelitian sebelumnya yang menggunakan uji-t untuk menguji keberadaan abnormal return. Pengujian abnormal return atas peristiwa pembayaran dividen di pasar modal Indonesia menggunakan uji-t sederhana mungkin masih relevan, dan investor mungkin dapat memperoleh manfaat dari cum-dividen dan tanggal pembayaran.
\end{abstract}

Kata Kunci: Dividen, Event Study, cum-dividen, pembayaran dividen, Abnormal Return

\begin{abstract}
This study revisits the market reactions on the dividend payment events, cum-dividend date and payment date using the event study method. The sample of this study includes all dividend announcements from 2017 to 2018 in the Indonesia Stock Exchange. This study performs various robust statistical tests proposed by Harrington and Shrider (2007). They point out that standard classical t-test is not enough to ensure abnormal return on an event because of the bias due to volatility caused by an event. Using various statistical tests for testing the abnormal return, this study shows that the market indeed reacts to the cum-dividend date and dividend payment date, as well as showing that the classical t-test showing the same conclusion as the other tests. Thus, this study validates the previous studies that used t-test to test the presence of abnormal return. Testing abnormal return on dividend payment events on the Indonesia capital market using a simple t-test might still be relevant, and the investors might be able to benefit from the cum-dividend and the payment dates.
\end{abstract}

Keywords: Dividend, Event Study, cum-dividend, dividend payment, Abnormal Return

\section{PENDAHULUAN}

Metode studi peristiwa (event study) adalah metode penelitian empiris yang digunakan dalam penelitian empiris bidang keuangan yang pertama kali diperkenalkan oleh Fama, Fisher, Jensen dan Roll (1969). Metode ini digunakan untuk melihat perilaku harga dari sebuah efek di sekitar sebuah peristiwa relevan yang terjadi. Kemudian metode ini menjadi sebuah metode standar di bidang penelitian empiris bidang keuangan. Adanya reaksi pasar atas sebuah peristiwa menunjukkan relevansi dari sebuah peristiwa tersebut terhadap nilai perusahaan. Dengan demikian, metode studi peristiwa menjadi sebuah alat standar dan dapat dipertanggungjawabkan secara ilmiah, yang dapat digunakan secara praktis untuk menguji berbagai teori terkait dengan faktor apa yang dapat mempengaruhi nilai sebuah perusahaan. 
Performance. Volume 27 Nomor 2 Tahun 2020, 23-38

Namun demikian, penelitian Harrington dan Shrider (2007) menunjukkan bahwa pengujian statistik yang dibutuhkan untuk meyakinkan adanya abnormal return pada suatu peristiwa tidak cukup hanya dengan uji-t klasik karena adanya bias akibat volatilitas yang disebabkan oleh suatu peristiwa yang menyebabkan type I error pada uji hipotesis. Untuk itu, dibutuhkan metode uji statistik yang lebih robust yang dapat mengatasi bias dari masalah yang dimaksud untuk membuktikan bahwa abnormal return benar terjadi pada masa periode amatan sebuah penelitian.

Salah satu topik di dalam keuangan yang pengujiannya menggunakan metode studi peristiwa adalah teori tentang dividen yang pertama kali perkenalkan oleh Miller dan Modigliani (1961). Teori tersebut menyimpulkan bahwa dividen tidak memengaruhi nilai perusahaan dalam kondisi pasar modal sempurna. Mereka berpendapat bahwa hanya kebijakan investasi yang dapat memengaruhi nilai perusahaan. Sejak itu apakah pembayaran dividen berpengaruh terhadap nilai perusahaan menjadi motivasi bagi para peneliti setelahnya, mengingat pada kenyataannya pasar tidaklah sempurna. Dengan demikian, apakah pembayaran dividen memiliki pengaruh terhadap nilai perusahaan dan bagaimana pengaruhnya tetap menjadi pertanyaan riset yang relevan di bidang keuangan karena pada dasarnya tujuan manajemen keuangan adalah untuk memaksimalkan nilai perusahaan.

Black dan Scholes (1974) menguji secara empiris pengaruh dividend yield terhadap harga saham dengan cara memodifikasi uji Capital Asset Pricing Model (CAPM) dan menemukan bahwa harga saham tidak dipengaruhi oleh dividend yield. Penelitian ini membuktikan preposisi dari Miller dan Modigliani (1961). Untuk membuktikan preposisi tersebut, kemudian sebuah metode yang dapat secara langsung menguji reaksi pasar dari dampak sebuah keputusan perusahaan, misalnya pembayaran dividen, dikembangkan Fama et al. (1969), yang pada dasarnya ditujukan untuk menguji hipotesis pasar efisien Fama (1970). Semenjak itu metode studi peristiwa banyak digunakan pada penelitian empiris keuangan untuk mengetahui reaksi pasar saham atas suatu peristiwa yang relevan yang ditunjukan dengan ada atau tidaknya abnormal return di sekitar tanggal peristiwa.

Dalam kaitannya dengan rangkaian peristiwa pembayaran dividen, studi peristiwa adalah bukti yang baik untuk menguji apakah pembayaran dividen relevan untuk nilai perusahaan atau tidak dengan memanfaatkan informasi dari suatu peristiwa tertentu. Tanggal cum-dividend adalah tanggal yang penting bagi investor; tanggal atau hari terakhir di mana jika investor masih tercacat pada tanggal tersebut sebagai pemegang saham perusahaan, maka investor berhak mendapatkan pembayaran dividen. Tanggal cum-dividend dapat berperan untuk memberikan kepercayaan yang lebih kepada investor terhadap suatu perusahaan mengingat nilai atau besar dividen yang akan dibayarkan sudah diketahui pada tanggal tersebut sehingga dapat ditangkap sebagai sinyal mengenai kondisi perusahaan oleh investor. Pada beberapa waktu menjelang tanggal cum-dividend beberapa literatur menunjukkan adanya abnormal return positif, misalnya penelitian Raymond (2017), Lestari, Arif, dan Wijayantini (2018) serta Lavista dan Utami (2017), menunjukkan bahwa investor melakukan aksi beli untuk mendapatkan dividen. Sementara itu, menurut hipotesis Clientele, pada sekitar Payment-Date diketahui terdapat respon pasar yang bersifat negatif sehingga menyebabkan penurunan harga saham karena pembayaran dividen, peristiwa ini diartikan sebagai informasi negatif karena adanya uang keluar untuk pembayaran dividen dari perusahaan. Periode menjelang pembayaran dividen diawali dengan berlalunya tanggal cum-dividend, dengan demikian harga saham akan mulai turun karena aksi jual yang dilakukan investor. Pada konteks ini investor merealisasikan keuntungan dari kenaikan harga saham menjelang tanggal cum-dividend.

Penelitian terdahulu di Indonesia yang menguji abnormal return pada pasar yang dilakukan oleh Kusno dan Hartanto (2018), Raymond (2017), Haryanto (2011), Endri (2009), dan Lavista dan Utami (2017) menunjukan bahwa pengujian statistik hanya menggunakan satu metode, yaitu uji-t klasik. Dengan berbagai permasalahan yang disebutkan oleh Harrington dan Shrider (2007), maka simpulan dari berbagai hasil studi yang menunjukkan adanya reaksi pasar pada peristiwa pembayaran dividen di pasar modal Indonesia harus ditinjau ulang. Oleh karena itu, penelitian ini 


\section{PERFORMANCE}

Jurnal Personalia, Financial, Operasional,

Marketing dau Sistem Informasi

Performance. Volume 27 Nomor 2 Tahun 2020, 23-38

bertujuan untuk menguji kembali reaksi pasar saham terhadap rangkaian peristiwa pembayaran dividen dengan berbagai metode statistik yang lebih robust, seperti yang disarankan di dalam artikel Harrington dan Shrider (2007).

\section{TINJAUAN PUSTAKA DAN PERUMUSAN HIPOTESIS}

Pada bagian ini dibahas beberapa penelitian empiris mengenai reaksi pasar atas berbagai rangkaian peristiwa pembayaran dividen perusahaan di pasar modal Indonesia. Endri (2009) melakukan penelitian mengenai pengumuman kebijakan dividen terhadap return saham yang masuk dalam Jakarta Islamic Index. Pengujian statistik yang digunakan adalah uji t. Penelitian ini menunjukkan bahwa terdapat abnormal return positif atas pengumuman pembagian dividen.

Raymond (2017) menguji pengaruh pengumuman pembayaran dividen terhadap harga saham sebelum dan sesudah tanggal ex-dividend pada industri manufaktur dan jasa yang terdaftar di Bursa Efek Indonesia selama periode 2012-2015. Metode pengujian abnormal return yang digunakan adalah Paired Sample t-test. Penelitian empiris ini membuktikan bahwa terdapat perbedaan harga saham sebelum dan sesudah ex-dividend date.

Haryanto (2011) menguji reaksi investor terhadap pengumuman dividen di Bursa Efek Indonesia untuk perusahaan-perusahaan yang termasuk LQ45 2007-2009 yang membagikan dividen tunai terus menerus. Uji analisis statistik yang digunakan adalah uji beda (ujit t) atas Average Abnormal Return (AAR) sebelum dan sesudah pengumuman dividen. Hasil penelitian ini menunjukkan bahwa tidak terdapat reaksi investor atas peristiwa tersebut; tidak ada perbedaan AAR sebelum dan sesudah pengumuman dividen.

Lavista dan Utami (2017) melakukan pengujian atas reaksi pasar di sekitar cum-dividend Date di Burs Efek Indonesia. Hasil temuan penelitian ini menunjukan bahwa terdapat abnormal return positif yang signifikan pada tanggal cum-dividend dan terdapat juga perbedaan signifikan abnormal return dan aktivitas volume perdagangan antara tanggal cum-dividend dan setelah tanggal cum-dividend.

Kusno dan Hartanto (2018) melihat dampak pengumuman pembagian dividen Kas terhadap abnormal return pada indeks LQ-45. Model penghitungan yang digunakan untuk mendapatkan expected rerturn adalah market model, dengan uji signifikansinya untuk melihat ada atau tidaknya abnormal return tersebut dengan uji statistik one-tailed $t$ test. Penelitian ini menyimpulkan bahwa terdapat abnormal return pada periode $\mathrm{H}+2, \mathrm{H}+4$, dan $\mathrm{H}+5$ setelah pengumuman mengenai pembayaran dividen.

Penelitian Lestari, Arif, dan Wijayantini (2018) melihat perubahan harga saham pada tanggal di sekitar cum-dividen date. Sampel penelitian terdiri dari 37 perusahaan manufaktur yang secara konsisten membayar dividen selama tahun 2014 hingga 2016. Metode pengujian yang digunakan adalah uji beda rata-rata (uji t). Penelitian ini menemukan bahwa pada tanggal cum-dividend, harga saham cenderung lebih tinggi dari tanggal-tanggal sebelumnya.

Berdasarkan penelitian terdahulu yang sudah dilakukan, diketahui bahwa hampir seluruh uji statistik yang digunakan untuk uji signifikansi adalah uji t yang mana telah dijelaskan sebelumnya bahwa dibutuhkan uji statistik lain yang lebih robust untuk memastikan adanya abnormal return, hal ini didukung dengan adanya hasil penelitian yang menunjukan bahwa tidak ada abnormal return di pasar saham terhadap peristiwa pembayaran dividen.

Dari pembahasan di atas dapat disimpulkan bahwa tanggal cum-dividend adalah tanggal yang penting bagi investor; tanggal atau hari terakhir yang mana jika investor masih tercacat pada tanggal tersebut sebagai pemegang saham perusahaan, maka investor berhak mendapatkan pembayaran dividen. Tanggal cum-dividend dapat berperan untuk memberikan kepercayaan yang lebih kepada investor terhadap suatu perusahaan mengingat nilai atau besar dividen yang akan dibayarkan sudah diketahui pada tanggal tersebut sehingga dapat ditangkap sebagai sinyal mengenai kondisi perusahaan oleh investor. 


\section{PERFORMANCE}

Jurnal Personalia, Financial, Operasional,

Marketing dau Sistem Informasi

Performance. Volume 27 Nomor 2 Tahun 2020, 23-38

Beberapa penelitian menunjukkan terdapat abnormal return positif pada beberapa waktu menjelang tanggal cum-dividend, misalnya penelitian Raymond (2017), Lestari, Arif, dan Wijayantini (2018) serta Lavista dan Utami (2017). Temuan ini mengimplikasikan bahwa bahwa investor melakukan aksi beli untuk mendapatkan dividen. Sementara itu, menurut hipotesis Clientele, pada sekitar Payment-Date terdapat respon pasar yang bersifat negatif sehingga menyebabkan penurunan harga saham karena pembayaran dividen. Peristiwa ini diartikan sebagai informasi negatif karena adanya uang keluar untuk pembayaran dividen dari perusahaan. Periode menjelang pembayaran dividen diawali dengan berlalunya tanggal cum-dividend. Dengan demikian, harga saham akan mulai turun karena aksi jual yang dilakukan investor. Pada konteks ini investor merealisasikan keuntungan dari kenaikan harga saham menjelang tanggal cumdividend. Berdasarkan kajian literatur di atas, maka hipotesis yang diajukan pada penelitian ini adalah sebagai berikut:

$\mathrm{H} 1$ : Terdapat reaksi pasar di sekitar tanggal cum-dividend

$\mathrm{H} 2$ : Terdapat reaksi pasar di sekitar tanggal pembayaran dividen

\section{METODE PENELITIAN}

Data yang digunakan dalam penelitian ini merupakan data sekunder yang terdiri dari harga penutupan saham harian perusahaan, data harga penutupan IHSG harian, tanggal cum dividend (Cum-Date), tanggal ex dividend (Ex-Date), dan tanggal pembayaran dividen (Payment-Date). Datadata sekunder tersebut diperoleh melalui website Bursa Efek Indonesia yaitu www.idx.co.id dan website Yahoo Finance. Sampel penelitian ini adalah seluruh pembayaran dividen di Bursa Efek Indonesia dalam periode tahun 2017 dan tahun 2018 dan perusahaan yang melakukan pembayaran dividen tidak melakukan aksi korporasi lainnya seperti stock split dan merger atau akuisisi pada jendela peristiwa amatan. Berdasarkan kriteria dan persyaratan di atas, didapatkan sebanyak 452 sampel yang memenuhi persyaratan dan akan dijadikan sampel pada penelitian ini.

Pada penelitian ini akan digunakan metode studi peristiwa yang bertujuan untuk menguji reaksi pasar saham terhadap rangkaian peristiwa pembayaran dividen pada sekitar tanggal cumdividend (ex-dividend) dan tanggal pembayaran dividen sebagai $t=0$ dan kemudian akan dilihat reaksi pasar saham dalam bentuk Cumulative Average Abnormal Return (CAAR) pada beberapa jendela peristiwa. Terdapat beberapa variabel yang perlu dilakukan penghitungan terlebih dahulu untuk menghitung abnormal return pada suatu jendela peristiwa, antara lain Return Aktual (Actual Return), Return Pasar (Market Return) dan Return yang diharapkan (Expected Return).

Return aktual dihitung dengan cara sebagai berikut:

$$
R_{i t}=\frac{P i t-P_{i t-1}}{P_{i t-1}}
$$

Di mana:

$R_{i t} \quad=$ return atau pengembalian saham perusahaan i pada periode waktu $\mathrm{t}$

Pit = harga saham perusahaan i pada periode waktu $\mathrm{t}$

$P_{i t-1} \quad=$ harga saham perusahaan i pada periode waktu t-1 (hari sebelumnya)

Return pasar akan menjadi salah satu variabel dalam penghitungan return ekspektasi pada studi peristiwa ini. Return pasar dihitung dengan cara sebagai berikut:

$$
R_{m t}=\frac{P m t-P_{m t-1}}{P_{m t-1}}
$$


Di mana:

$R_{m t} \quad=$ return atau pengembalian pasar (IHSG) pada periode waktu $\mathrm{t}$

Pmt = harga pasar (IHSG) pada periode waktu t

$P_{m t-1} \quad=$ harga pasar (IHSG) pada periode waktu t-1 (hari sebelumnya)

Abnormal return merupakan selisih dari pengembalian saham aktual dan pengembalian yang diharapkan (expected return) pada jendela peristiwa (event window). Pengukuran pengembalian yang diharapkan dilakukan dengan menggunakan pendekatan model pasar yang mengukur hubungan antara pengembalian saham yang diberikan dan pengembalian saham pasar, sehingga didefinisikan:

$$
E R_{i t}=\alpha_{i}+\beta_{i} R_{m t}+\varepsilon_{i t}
$$

Di mana:

$E R_{i t} \quad=$ expected return atau pengembalian saham perusahaan i pada waktu $\mathrm{t}$

$R_{m t} \quad=$ return atau pengembalian saham pasar pada waktu $\mathrm{t}$.

Periode estimasi yang digunakan untuk melakukan penghitungan return pengembalian yang diharapkan yaitu mulai dari 270 hari sampai dengan 20 hari sebelum tanggal peristiwa [-270,-20] kemudian dilakukan estimasi regresi antara data historis pengembalian saham perusahaan dan pengembalian pasar dalam periode estimasi untuk mendapatkan $\alpha_{i}$ dan $\beta_{i}$ dari setiap perusahaan. Parameter $\alpha_{i}$ dan $\beta_{i}$ adalah parameter estimasi yang diperoleh dari penghitungan regresi tersebut. Estimasi regresi untuk mengetahui return yang diharapkan dilakukan selama jendela peristiwa yaitu 5 hari sebelum tanggal peristiwa sampai dengan 5 hari setelah tanggal peristiwa $[-5,+5]$. Jendela peristiwa ini dipilih berdasarkan beberapa penelitian terdahulu mengenai uji abnormal return pada cum-dividend date, misalnya penelitian Koski \& Scruggs (1998) dan Kadapakkam \& Martinez (2008). Berikut adalah gambaran periode estimasi dan jendela peristiwa yang digunakan dalam penelitian ini.

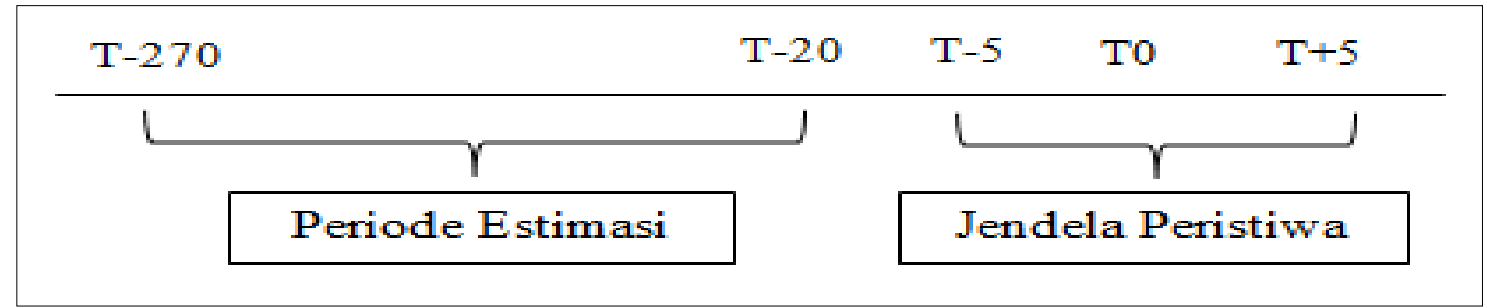

Gambar 1. Gambaran Periode Estimasi dan Jendela Peristiwa

Selain jendela peristiwa $[-5,+5]$, penelitian ini juga akan menggunakan jendela peristiwa yang lebih pendek, yakni $[-3,+3]$ sebagai salah satu uji robustness, untuk mengurangi kemungkinan adanya confounding effects di sekitar tanggal cum-dividend. Selain menggunakan jendela peristiwa yang simestris seperti yang telah disebutkan sebelumnya, penelitian ini juga menggunakan jendela peristiwa asimetris untuk menangkap secara lebih jelas reaksi dan aksi investor sebelum dan sesudah periode peristiwa dengan melihat tanda dari abnormal return pada sebelum dan sesudah peristiwa terjadi. Dengan demikian akan digunakan peristiwa jendela $[-5,0]$ dan $[-3,0]$ untuk sebelum tanggal cum-dividend dan $[0,1]$ dan $[0,2]$ untuk periode setelah peristiwa. Kemudian jendela peristiwa asimetris yang akan digunakan untuk sebelum tanggal pembayaran dividen (dividend payment date) adalah $[-5,0],[-3,0],[-1,0]$ dan untuk setelah tanggal pembayaran dividen adalah $[0,1],[0,3],[0,5]$. Langkah selanjutnya yang dilakukan dalam penelitian ini adalah mengukur abnormal return, dinyatakan dengan persamaan berikut:

$$
A R_{i t}=R_{i t}-E R_{i t}
$$


Performance. Volume 27 Nomor 2 Tahun 2020, 23-38

Di mana $R_{i t}$ adalah return atau pengembalian saham aktual perusahaan i pada periode waktu $t$ dan $E R_{i t}$ adalah pengembalian yang diharapkan yang diukur melalui persamaan (3).

Average abnormal returm dihitung dengan cara sebagai berikut:

$$
\mathrm{AAR}_{t}=\frac{\sum A R_{i t}}{N}
$$

Di mana:

$\sum A R_{i t}=$ Total Abnormal Return perusahaan i pada waktu $\mathrm{t}$

$N=$ Jumlah perusahaan yang menjadi sampel penelitian .

Akumulasi rata-rata abnormal return (cumulative abnormal return) dihitung dengan cara sebagai berikut:

$$
\mathrm{CAAR}_{i}=\sum_{t=t 1}^{t 2} \mathrm{AAR}_{t}
$$

Di mana $t_{1}$ dan $t_{2}$ mewakili batas bawah dan batas atas dari setiap jendela peristiwa yang sudah ditentukan.

Kemudian, untuk mengetahui ada atau tidaknya abnormal return akan digunakan berbagai uji statistik seperti yang dibahas pada artikel Harrington dan Shrider (2007). Berbagai uji statistik tersebut dirangkum sebagai berikut.

\section{Uji t (Cross-Sectional Standard Deviation Test)}

Pada Uji t (Cross-Sectional Standard Deviation Test), uji statistik dilakukan dengan membagi AAR dan CAAR pada periode waktu yang akan diuji dengan standar deviasi cross-sectional. Uji Statistik $t$ untuk Ho: $A A R=0$ dapat diperoleh melalui penghitungan sebagai berikut:

$$
t=\frac{A A R_{t}}{\frac{\partial A A R_{t}}{\sqrt{N}}}
$$

Di mana:

$A A R_{t} \quad=$ Average Abnormal Return periode waktu $\mathrm{t}$

$\hat{\sigma} A A R_{t} \quad=$ Standar Deviasi Average Abnormal Return periode waktu $\mathrm{t}$

$N \quad=$ Jumlah sampel yang digunakan dalam penelitian

Variabel $\widehat{\sigma^{2}} A A R_{t}$ diperoleh dengan persamaan:

$$
\widehat{\sigma^{2}} A A R_{t}=\frac{1}{N-1} \sum_{i=1}^{N}\left(A R_{i t}-\frac{1}{N} \sum_{j=1}^{N} A R_{j t}\right)^{2}
$$

Di mana $A R_{i t}$ adalah Abnormal Return dari saham perusahaan i pada periode waktu t.

Kemudian untuk uji statistik Ho: CAAR $=0$ dijelaskan sebagai berikut.

$$
t_{C A A R}=\frac{C A A R_{T 1 T 2}}{\frac{\partial C A A R_{11 T 2}}{\sqrt{N}}}
$$

Variabel $\widehat{\sigma^{2}} A A R_{t}$ diperoleh dengan persamaan:

$$
\widehat{\sigma}^{2} C A A R_{T 1, T 2}=\frac{1}{N-1} \sum_{i=1}^{N}\left(C A R_{i, T 1, T 2}-\frac{1}{N} \sum_{j=1}^{N} C A R_{j, T 1, T 2}\right)^{2}
$$


Jurnal Personalia, Financial, Operasional,

Marketing dam Sistem Informasi

Performance. Volume 27 Nomor 2 Tahun 2020, 23-38

Patell Test of Standardized Residuals (Patell, 1976).

Patell (1976) menerapkan prosedur pengujian untuk mendeteksi efek rata-rata menggunakan standardized prediction error pada setiap sampel sekuritas untuk setiap hari di jendela peristiwa, sebagai berikut:

$$
S A R_{i t}=\frac{A R_{i t}}{S_{i} C_{i t}}
$$

Di mana:

$S_{i} \quad=$ Standar error residu dari estimasi regresi market model pada periode estimasi

$C_{i t} \quad=$ Faktor penyesuaian

Standar errror residu diperoleh dengan persamaan berikut:

$$
S^{2}{ }_{i}=\frac{1}{N-2} \sum_{t=1}^{T}\left(A R_{i t}\right)^{2}
$$

Faktor penyesuaian yang dimaksud dijabarkan dengan model matematika sebagai berikut:

$$
C_{i t}=\sqrt{1+\frac{1}{T_{i}}+\frac{\left(R_{m t}-\overline{R_{m}}\right)^{2}}{\sum_{t=1}^{T 1}\left(R_{m t}-\overline{R_{m}}\right)^{2}}}
$$

Di mana:

$T_{i} \quad=$ panjang periode estimasi perusahaan $\mathrm{i}$

$R_{m t} \quad=$ return pasar di periode $t$ pada jendela peristiwa

$\overline{R_{m}} \quad=$ return pasar rata-rata pada periode estimasi

Adapun return pasar rata-rata diperoleh dengan penghitungan sebagai berikut:

$$
\overline{R_{m}}=\frac{1}{T_{i}} \sum_{t=1}^{T_{i}} R_{m t}
$$

Total SAR (TSARt) untuk periode waktu tertentu, t, diperoleh dari akumulasi SAR seluruh sekuritas.

$$
\operatorname{TSAR}_{t}=\sum_{i=1}^{N} S A R_{i t}
$$

Kemudian test statistik Patell untuk Ho: $A A R=0$ didapatkan dengan membagi $T S A R_{t}$ dengan standard error.

$$
\text { Z Patell, } t: \frac{T S A R_{t}}{\left[\sum_{I=\frac{1}{T_{i}-2}}^{T_{T^{-}-4}}\right]^{1 / 2}}
$$

Uji statistik untuk Cumulative Average Abnormal Return $\left(\operatorname{CAAR}_{T 1, T 2}\right)=0$ dapat dilakukan dengan persamaan:

$$
\text { Z Patell : } \frac{1}{\sqrt{N}}\left(\frac{\sum_{t=T 1}^{T 2} S A R_{i t}}{\sqrt{\left(T_{1}-T_{2}+1\right)\left(\frac{T i-2}{T i-4}\right)}}\right)
$$

\section{Boehmer Test of Standardized Residuals Corrected for Event-Induced Changes in Volatility (Boehmer Et Al., 1991).}

Boehmer et al. (1991) mengusulkan prosedur standardized cross-sectional yang robust di bawah varians yang diinduksi oleh peristiwa. Namun, prosedur ini masih memerlukan asumsi residu atau abnormal return yang tidak berkorelasi. Uji Statistik BMP untuk Ho: AAR $=0$ dapat diperoleh melalui penghitungan sebagai berikut: 
Jurnal Personalia, Financial, Operasional,

Marketing dau Sistern Informasi

Performance. Volume 27 Nomor 2 Tahun 2020, 23-38

$$
Z B M P, t: \frac{T S A R_{t}}{N^{\frac{1}{2}} S\left(S A R_{t}\right)}
$$

Di mana:

$T_{S A R} \quad=$ Total Standardized Abnormal Return di periode $\mathrm{t}$

$S_{\left(S A R_{t}\right)} \quad=$ Standar deviasi Standardized Abnormal Return di periode $\mathrm{t}$

$N=\quad$ = Jumlah sampel yang digunakan dalam penelitian.

Standar deviasi dari $\operatorname{SAR}_{t}\left(S_{\left(S A R_{t}\right)}\right)$ didapatkan berdasarkan persamaan (19) berikut:

$$
S_{\left(S A R_{t}\right)}^{2}=\frac{1}{N-1} \sum_{t=1}^{N}\left(S A R_{i, t}-\frac{1}{N} \sum_{j=1}^{N} S A R_{j, t}\right)^{2}
$$

Untuk variabel $S A R_{i, t}$ diperoleh melalui penghitungan pada persamaan (11), Uji Statistik BMP untuk Ho: $C A A R=0$ dapat diperoleh melalui penghitungan sebagai berikut:

$$
Z_{t}=\frac{\sum_{i=0}^{N} \operatorname{SCAR}_{T_{1 i}, T_{2 i}}}{N^{\frac{1}{2}}\left(S_{S C A R}\left(T_{1 i} T_{2 i}\right)\right.}
$$

Variabel $S C A R_{T_{1 i}, T_{2 i}}$ dan $S_{S C A R_{\left(T_{1 i}, T_{2 i}\right)}}$ dapat diperoleh melalui persamaan (21) dan (23).

$$
\operatorname{SCAR}_{T_{1 i}, T_{2 i}}=\frac{\operatorname{CAR}_{T_{1 i} T_{2 i}}}{S_{C A T_{1 i} T_{2 i}}}
$$

Dimana $S_{C_{A R} T_{1 i}, T_{2 i}}$ merupakan standar deviasi dari $C A R_{T_{1 i}, T_{2 i}}$ yang diperoleh dengan penghitungan sebagai berikut:

$$
S^{2}{ }_{C A R_{T_{1 i}, T_{2 i}}}=\frac{1}{N-2} \sum_{t=1}^{T}\left(A R_{i t}\right)^{2}\left(L+\frac{L^{2}}{T_{i}}+\frac{\left(\sum_{t=T_{1} R_{m t}}^{T 2} \overline{R_{m}}\right)^{2}}{\sum_{t=1}^{T 1}\left(R_{m t}-\overline{R_{m}}\right)^{2}}\right)
$$

$L$ merupakan panjang jendela peristiwa $\left(T_{2}-T_{1}+1\right)$ dan $T_{i}$ merupakan panjang dari periode estimasi.

$$
S_{S C A R_{\left(T_{1 j}, T_{2 j}\right)}}=\frac{1}{N-1} \sum_{i=1}^{N}\left(\operatorname{SCAR}_{T_{1 i}, T_{2 i}}-\frac{1}{N} \sum_{j=1}^{N} S C A R_{T_{1 j}, T_{1 j}}\right)^{2}
$$

Brown and Warner's Crude Dependence Adjustment for Event Clustering (Brown and Warner, 1980).

Brown dan Warner (1980) menyarankan prosedur yang disebut Crude Dependence Adjustment (CDA) untuk menjelaskan keterikatan antara residu rata-rata perusahaan. Prosedur yang disarankan didasarkan pada estimasi standar deviasi residu rata-rata dari deret waktu Average Abnormal Retrun selama periode estimasi. Uji statistiknya adalah distribusi t Student dengan derajat kebebasan $T-1$, dituliskan sebagai berikut untuk Ho: $A A R=0$ :

$$
t C D A=\frac{A A R_{t}}{\widehat{\sigma} A A R} \sim t_{T-1}
$$

$\hat{\sigma} A A R$ didapatkan melelui penghitungan:

$$
\hat{\sigma}^{2} A A R=\frac{1}{T-1} \sum_{t=T 1}^{T 2}\left[A A R_{t}-A R^{*}\right]^{2}
$$

Variable $A R^{*}=\sum_{t}^{T} \frac{A A R_{t}}{T}$; hasil penghitungan $A R^{*}$ digunakan untuk mencari $\hat{\sigma}^{2} A A R$ pada persamaan (25) diatas. 
Untuk uji statistik untuk Ho: CAAR $=0$ dijelaskan sebagai berikut:

$$
t C D A=\frac{C A A R_{t}}{(T 2-T 1+1)^{\frac{1}{2}} \widehat{\sigma} A A R} \sim t_{T-1}
$$

Kolari test of standardized residuals corrected for event-induced changes in volatility and crosscorrelation (Kolari dan Pynnönen, 2010).

Kolari dan Pynnönen, (2010) mengusulkan uji statistik yang memodifikasi t-statistik Boehmer, Musumeci, dan Poulsen (1991) untuk memperhitungkan cross-correlation dan menunjukkan bahwa uji statistik tersebut bekerja dengan baik jika dibandingkan dengan uji statistik lainnya, termasuk pendekatan portofolio, yang kurang kuat daripada uji statistik alternatif lain yang diteliti. Uji Statistik adjusted-BMP untuk Ho: $A A R=0$ dapat diperoleh melalui penghitungan sebagai berikut:

$$
t_{A B, t}=Z_{B M P, t}\left(\sqrt{\frac{1-\bar{r}}{1+(N-1) \bar{r}}}\right)
$$

Dimana $\bar{r}$ merupakan rata-rata dari cross-correlation abnormal return pada periode estimasi. Dengan kata lain jika $\bar{r}=0$ atau tidak terdapat cross-correlation abnormal return pada periode estimasi maka hasil penghitungan sama dengan uji statistik BMP sebelumnya pada persamaan (18). Kemudian untuk Uji Statistik adjusted-BMP untuk Ho: CAAR = 0 dapat diperoleh melalui penghitungan sebagai berikut:

$$
t_{A B}=Z_{B M P}\left(\sqrt{\frac{1-\bar{r}}{1+(N-1) \bar{r}}}\right)
$$

\section{Corrado Rank Test (Corrado, 1989).}

Corrado (1989) menjelaskan rank test untuk jendela peristiwa satu hari sebagai prosedur rank test dengan menggabungkan periode estimasi dan jendela peristiwa dan memberikan peringkat untuk setiap return harian untuk setiap perusahaan. Abnormal Return terkecil dalam periode estimasi gabungan dan jendela peristiwa ditetapkan dengan peringkat 1. Panjang jendela peristiwa adalah $L$ yang sama dengan $(T 2-T 1+1)$. Uji Statistik Corrado Rank Test adalah sebagai berikut:

$$
Z_{\text {rank }}=(T 2-T 1+1)^{\frac{1}{2}}\left\{\frac{\overline{K_{T 1 T 2}}-\widetilde{K}}{\left[\sum_{t=1}^{T+1} \frac{\left(\overline{K_{T}}-\widetilde{K}\right)^{2}}{T+L}\right]^{\frac{1}{2}}}\right\}
$$

Di mana :

$\overline{K_{T 1 T 2}}=$ Rank rata-rata dari seluruh $\mathrm{N}$ perusahaan dan $\mathrm{L}$ hari jendela peristiwa.

$T \quad=$ Jumlah hari periode estimasi

$L \quad=$ Jumlah hari jendela peristiwa

$\overline{K_{T}} \quad=$ Rata-rata rank dari seluruh $\mathrm{N}$ perusahaan pada hari ke-t di periode estimasi dan peristiwa

Variabel $\widetilde{K}$ diperoleh dengan persamaan (30) sebagai berikut :

$$
\widetilde{K}=\frac{(T+L+1)}{2} \text {.. }
$$

Kemudian $\overline{K_{T 1 T 2}}$ didapatkan dengan persamaan (31) dibawah ini:

$$
\overline{K_{T 1 T 2}}=\frac{1}{(T 2-T 1+1)} \sum_{t=T 1}^{T 2} \frac{1}{N} \sum_{i=1}^{N} K_{i t}
$$

Selain itu juga dibutuhkan persamaan yang menjelaskan variabel $\overline{K_{T}}$ sebagai berikut: 


$$
\overline{K_{T}}=\frac{1}{N} \sum_{i=1}^{N} K_{i t}
$$

\section{Corrado and Zivney Rank Test Corrected fFor Event-Induced Volatility of Rankings (Corrado dan Zivney, 1992)}

Tes nonparametrik yang diusulkan oleh Corrado-Zivney (1992) adalah modifikasi dari Rank Test yang dikembangkan oleh Corrado sebelumnya dimana digunakan untuk mengukur kinerja abnormal dalam studi peristiwa dan didasarkan pada peringkat yang terstandarisasi. Dengan cara ini, varian cross-sectional disesuaikan untuk penerapan pada data. Standar deviasi cross-sectional pada hari ke-0 didefinisikan sebagai berikut :

$$
S_{(S A R)}=\sqrt{\frac{1}{N-1} \sum_{t=1}^{N}\left(S A R_{i, 0}-\frac{1}{N} \sum_{j=1}^{N} S A R_{j, 0}\right)^{2}}
$$

Di mana berlaku:

$$
S A R_{i, t}=\left\{\begin{array}{lr}
t \neq 0, & \text { maka } S A R_{i, t} \\
t=0, & \text { maka } \frac{S A R_{i, t}}{S_{(S A R)}}
\end{array}\right.
$$

Penghitungan ranking pada Corrado dan Zivney (1992) dapat dilakukan sebagai berikut:

$$
K_{i, t}=\frac{\operatorname{rank}\left(\operatorname{SAR}_{i, t}\right)}{m+1}
$$

m merupakan jumlah non-missing return untuk perusahaan i.

Selanjutnya standar deviasi dari seluruh sampel penelitian pada periode estimasi dan jendela peristiwa didapatkan dengan persamaan berikut:

$$
S_{\bar{K}}=\sqrt{\frac{1}{M} \sum_{t=1}^{m}\left(\frac{N_{t}}{N}\left(\overline{K_{T}}-\frac{1}{2}\right)^{2}\right.}
$$

Sehingga uji statistiknya untuk Ho: $A A R=0$ menjadi:

$$
t_{R A N K}=\frac{\overline{K_{T}}-0,5}{S_{\bar{K}}}
$$

Di mana $\overline{K_{T}}$ diperoleh melalui persamaan (32) dan $S_{\bar{K}}$ diperoleh dari persamaan (35). Uji statistik untuk Ho: $\mathrm{CAAR}=0$ dijelaskan sebagai berikut:

$$
t_{R A N K}=\sqrt{L_{2}}\left(\frac{\overline{K_{T 1 T 2}}-0,5}{S_{\bar{K}}}\right) .
$$

Di mana $\overline{K_{T 1 T 2}}$ diperoleh melalui persamaan (31) dan $S_{\bar{K}}$ diperoleh dari persamaan (35).

\section{Generalized Sign Test (Cowan, 1992)}

Generalized Sign Test adalah versi yang disempurnakan dari sign test dengan memungkinkan hipotesis nol yang memiliki residu abnormal positif berbeda dari 0,5 (Cowan, 1992). Sign test adalah tes binomial sederhana untuk memastikan apakah frekuensi residu abnormal positif sama dengan 50\% atau tidak. Generalized Sign Test menyesuaikan fraksi abnormal return positif dalam periode estimasi daripada mengasumsikan 0,5. Generalized Sign Test membandingkan proporsi abnormal return positif di sekitar suatu peristiwa dengan proporsi dari periode yang tidak terpengaruh oleh peristiwa tersebut. Generalized Sign Test menguji apakah jumlah saham dengan abnormal return kumulatif positif di jendela peristiwa melebihi jumlah yang diharapkan tanpa 
Jurnal Personalia, Financial, Operasional,

Marketing dau Sistem Informasi

Performance. Volume 27 Nomor 2 Tahun 2020, 23-38

adanya kinerja abnormal atau tidak. Jumlah yang diharapkan didasarkan pada proporsi abnormal return positif dalam periode estimasi yang dihitung pada persamaan (38)

$$
\hat{\rho}=\frac{1}{N} \sum_{i=1}^{N} \frac{1}{T} \sum_{t=1}^{T} S_{i t}
$$

Di mana $S_{i t}$ didapatkan dari:

$$
S_{i t}= \begin{cases}1, & \text { if } A R_{i t}>0 \\ 0, & \text { lainnya }\end{cases}
$$

Generalized Sign Test diperoleh melalui persamaan dibawah ini :

$$
Z_{G}=\frac{w-N \widehat{\rho}}{\sqrt{N \widehat{\rho}(1-\widehat{\rho})}} \ldots
$$

Di mana:

$w=$ jumlah saham pada jendela peristiwa yang abnormal return kumulatifnya adalah positif.

\section{HASIL DAN PEMBAHASAN}

Data yang digunakan dalam uji ada atau tidaknya reaksi pasar atas rangkaian peristiwa pembayaran dividen adalah 452 pembayaran dividen dengan observasi selama periode tahun 2017 sampai 2018 untuk masing-masing tanggal Cum-Date dan Payment-Date. Kemudian untuk data return harian IHSG yang digunakan adalah pada periode tahun 2016 sampai dengan 2018. Berikut merupakan statistik deskriptif untuk return harga saham perusahaan harian dan IHSG.

Tabel 1. Statistik Deskriptif Return Harian Saham Perusahaan dan Return Harian IHSG (dalam desimal)

\begin{tabular}{ccccccc}
\hline & $\begin{array}{c}\text { Jumlah } \\
\text { Observasi }\end{array}$ & Min. & Median & Maks. & Mean & $\begin{array}{c}\text { Simpangan } \\
\text { Baku }\end{array}$ \\
\hline $\begin{array}{c}\text { Return } \\
\text { Perusahaan }\end{array}$ & 452 & $-0,8070$ & 0 & 1,0 & 0,000801 & 0,03077 \\
\hline Return IHSG & - & $-0,0400$ & 0,000786 & 0,02853 & 0,00044 & 0,00834 \\
\hline
\end{tabular}

Reaksi Pasar atas Cum-Date, Ex-Date

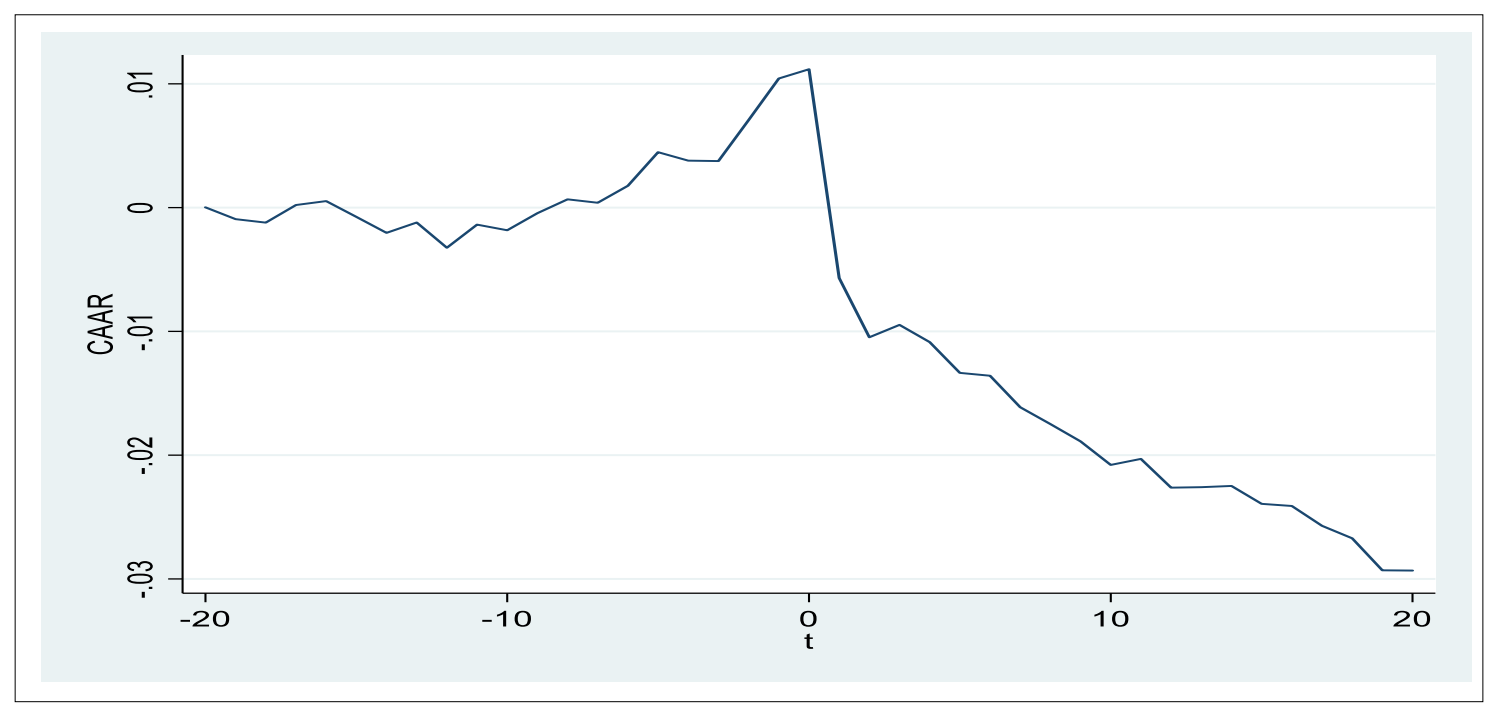

Gambar 2. Cumulative Average Abnormal Return di sekitar Peristiwa Cum-dividend 
Performance. Volume 27 Nomor 2 Tahun 2020, 23-38

Gambar 2 menunjukan adanya tren abnormal return positif yang sudah dimulai pada beberapa hari mendekati tanggal cum-dividend $(\mathrm{t}=0)$ dan mencapai puncaknya pada tanggal cum-dividend. Kemudian pada tanggal ex-dividend dimana merupakan satu hari setelah tanggal cum-dividend, terlihat terjadi penurunan abnormal return yang sangat tinggi dan selanjutnya trend negatif masih terus berlanjut sampai dengan 20 hari setelah tanggal cum-dividend. Untuk memastikan apakah tren tersebut dapat dikatakan sebagai sebuah bentuk reaksi pasar atas persitiwa dividen maka akan dilakukan uji statistik seperti yang telah dijabarkan di atas. Berikutnya pada Tabel 2 dilaporkan hasil uji statistik Average Abnormal Return pada jendela peristiwa 5 hari sebelum tanggal cum-dividend sampai dengan 5 hari setelah tanggal cum-dividend $(-5,5)$ :

Tabel 2. Average Abnormal return (AAR) pada t-5 s.d. t+5 Cum-Dividend

\begin{tabular}{cccccccccc}
\hline $\mathrm{t}$ & AAR & $\mathrm{t}$-test & CDA & Patell & Boehmer & Kolari & Corrado & Zivney & GenSign \\
\hline-5 & 0,0019252 & & & $*$ & & & & & $*$ \\
-4 & $-0,0006785$ & & & & & & & & \\
-3 & $-0,0000569$ & & & & & & & & \\
-2 & 0,0037226 & $* * *$ & $* *$ & $* *$ & $* *$ & & $* *$ & $* *$ & $* * *$ \\
-1 & 0,002119 & & & & & & $*$ & $*$ & $* *$ \\
0 & 0,0018018 & & & & & & & & $*$ \\
1 & $-0,017046$ & $* * *$ & $* * *$ & $* * *$ & $* * *$ & $* * *$ & $* * *$ & $* * *$ & $* * *$ \\
2 & $-0,004221$ & $* * *$ & $* * *$ & $* * *$ & $* * *$ & $* * *$ & $* * *$ & $* * *$ & $* * *$ \\
3 & 0,0005067 & & & & & & & & \\
4 & $-0,001628$ & & & $* *$ & $* *$ & & & & $* *$ \\
5 & $-0,0026493$ & $*$ & $*$ & $*$ & $*$ & & & & \\
\hline
\end{tabular}

$* * *, * *, *$ menunjukkan signifikansi pada alfa 1,5 , dan $10 \%$

Pada Tabel 2 ditunjukkan bahwa pada t-2 sampai dengan t-1 sebelum tanggal cum-dividend terdapat average abnormal return positif sebesar 0.0037226 dan $0.002119^{1}$. Average Abnormal Return positif di t-2 signifikan pada level 1\% (sesuai uji t dan uji Generalized Sign) dan pada level 5\% (sesuai uji Crude Dependence Adjustment, Uji Patell, Uji Boehmer atau BMP test, Uji Corrado dan Uji Zivney). Dari delapan uji statistik tersebut hanya uji Kolari yang tidak signifikan secara statistik sedangkan Average Abnormal Return positif di t-1 signifikan pada level 5\% (sesuai Uji Generalized Sign) dan pada level 10\% (Uji Corrado dan Uji Zivney). Melalui hasil pengujian signifikansi Average Abnormal Return tersebut, diketahui bahwa uji t secara konsisten didukung oleh sebagian besar uji statistik lainnya. Hasil temuan ini sejalan dengan hasil penelitian yang sudah dilakukan sebelumnya oleh Lavista \& Utami (2017) serta Lestari, Arif, dan Wijayantini (2018), bahwa terdapat indikasi adanya abnormal return positif pada satu sampai dua hari menjelang tanggal cum-dividend. Hal ini dapat disebabkan karena tanggal cum-dividend merupakan tanggal terakhir di mana investor yang akan membeli saham suatu perusahaan dapat memiliki hak dalam pembagian dividen perusahaan tersebut, sehingga aksi pembelian saham suatu perusahaan yang akan membagikan dividen tersebut meningkat.

Pada $\mathrm{t}+1$ dan $\mathrm{t}+2$ setelah tanggal cum-dividend terlihat indikasi adanya Average Abnormal Return negatif yang signifikan sebesar -0.017046 dan -0.004221 . Average Abnormal Return negatif di periode $\mathrm{t}+1$ dan $\mathrm{t}+2$ signifikan pada level $1 \%$, ditunjukkan oleh kedelapan uji signifikansi yang digunakan. Melalui hasil pengujian statistik Average Abnormal Return tersebut, ditunjukkan bahwa uji t secara konsisten didukung oleh seluruh uji signifikansi lainnya. Perilaku penurunan harga yang tinggi pada periode waktu tersebut sesuai dengan penelitian Ngoc \& Cuong (2016) dan Raymond (2017). Seperti yang telah diketahui bahwa periode waktu $\mathrm{t}+1$ dari tanggal cum-dividend merupakan tanggal exdividend. Tanggal ex-dividend adalah hari pertama bagi investor yang membeli saham suatu perusahaan tidak berhak dalam pembagian dividen yang akan dibagikan sehingga pada tanggal ex-

\footnotetext{
${ }^{1}$ Demi kemudahan untuk dibaca dan dipahami, hasil t atau z hitung serta nilai $p$ tidak dilaporkan pada table namun ada pada lampiran.
} 


\section{PERFORMANCE}

Jurnal Personalia, Financial, Operasional,

Marketing dau Sistem Informasi

Performance. Volume 27 Nomor 2 Tahun 2020, 23-38

dividend ini pemegang saham banyak melakukan penjualan saham yang menyebabkan harga saham perusahaan tersebut mengalami penurunan.

Kemudian untuk melihat ada atau tidaknya abnormal return di sekitar peristiwa $(\mathrm{t}=0)$ maka akan diuji apakah terdapat cumulative average abnormal return (CAAR) dengan menggunakan berbagai uji statistik yang telah dijelaskan di atas. Terdapat enam jendela peristiwa yang digunakan dalam pengujian ini. Hasil pengujian CAAR disajikan pada Tabel 3. Pada jendela peristiwa sebelum tanggal cum-dividend yaitu $[-5,0]$ dan $[-3,0]$ ditemukan CAAR yang bernilai positif dan signifikan yangdidukung oleh seluruh uji statistik yang digunakan, kecuali uji Kolari). Hasil ini mendukung hasil temuan pada AAR sebelumnya bahwa beberapa hari sebelum CumDate harga saham perusahaan terus mengalami peningkatan, kemudian pada jendela peristiwa [$3,1]$ dan $[-3,3]$ terlihat adanya CAAR negatif dan signifikan yang mengimplikasikan bahwa adanya penurunan harga saham yang tinggi mengakibatkan secara kumulatif return yang diperoleh investor adalah negatif. Kemudian pada jendela peristiwa setelah tanggal cum-dividend yaitu $[0,1]$ dan $[0,2]$, CAAR yang diperoleh bernilai negatif dan signifikan secara statistik. Hal ini disebabkan AAR yang terdapat pada Tabel 2 , di periode waktu $t+1$ dimana merupakan tanggal ex-dividend diperoleh nilai AAR negatif yang signifikan dan hal yang sama pada priode waktu $t+2$. Secara visual dapat dilihat pada Gambar 1 diketahui bahwa terdapat penurunan CAAR yang tinggi pada waktu setelah tanggal cum-dividend memasuki tanggal ex-dividend. Melalui hasil pengujian statistik CAAR pada beberapa jendela peristiwa di atas, dapat dilihat bahwa uji t secara konsisten didukung oleh seluruh uji statistik yang digunakan. Dengan demikian berbagai hasil uji statistik ini mendukung hipotesis pertama bahwa terdapat reaksi pasar atas peristiwa pembayaran dividen, yaitu di sekitar tanggal cum-dividend.

Tabel 3. Cumulative Average Abnormal Return(CAAR) di sekitar Cum-Dividend

\begin{tabular}{cccccccccc}
\hline $\mathrm{t}$ & CAAR & $\begin{array}{c}\mathrm{t}- \\
\text { test }\end{array}$ & CDA & Patell & Boehmer & Kolari & Corrado & Zivney & GenSign \\
\hline$[-5 ; 0]$ & 0,008577 & $* *$ & $* *$ & $* * *$ & $*$ & & $* * *$ & $* * *$ & $* *$ \\
{$[-3 ; 0]$} & 0,00754 & $* * *$ & $* *$ & $* * *$ & $* *$ & & $* * *$ & $* * *$ & $* * *$ \\
{$[-3 ; 1]$} & $-0,00946$ & $* * *$ & $* * *$ & $* *$ & & & & & $* * *$ \\
{$[-3 ; 3]$} & $-0,01326$ & $* * *$ & $* * *$ & $* * *$ & $* * *$ & $* *$ & $* *$ & & $* * *$ \\
{$[0 ; 1]$} & $-0,01496$ & $* * *$ & $* * *$ & $* * *$ & $* * *$ & $* * *$ & $* * *$ & $* * *$ & $* * *$ \\
{$[0 ; 2]$} & $-0,01971$ & $* * *$ & $* * *$ & $* * *$ & $* * *$ & $* * *$ & $* * *$ & $* * *$ & $* * *$ \\
\hline
\end{tabular}

$* * *, * *, *$ menunjukkan signifikansi pada alfa 1,5 , dan $10 \%$

\section{Reaksi Pasar atas Payment-Date}

Selain tanggal cum-dividend dan tanggal ex-dividend, terdapat tanggal lain dalam rangkaian peristiwa pembayaran dividen yang diduga memiliki kandungan informasi bagi investor, yaitu tanggal pembayaran dividen. Tanggal pembayaran dividen adalah hari (tanggal) di mana perusahaan membayarkan dividen kepada para investor yang sudah tercatat memiliki hak untuk menerima pembayaran dividen.

Grafik 3 menunjukkan terdapat abnormal return negatif yang terdapat pada periode waktu t-20 dan juga disekitar tanggal peristiwa $(\mathrm{t}=0)$ yang merupakan tanggal pembayaran dividen. $T$ Tabel 4 menunjukkan hasil pengujian average abnormal return (AAR) masing-masing waktu dari t-5 sampai dengan $t+5$ beserta dengan hasil dari berbagai uji statistik yang digunakan dalan penelitian ini. Tabel 4 menunjukkan bahwa pada $\mathrm{t}-5$ sampai dengan $\mathrm{t}=0$ average abnormal return yang diperoleh adalah negatif kecuali pada t-2 yang bernilai positif. Jika dilihat signifikansinya, average abnormal return pada t-1 Payment-date bernilai negatif dan signifikan pada level 5\% (sesuai dengan uji t, uji Crude Dependence Adjustment, Uji Patell, Uji Boehmer atau BMP test, dan uji Generalized Sign) dan level 10 $\%$ (sesuai Uji Kolari). Kemudian, pada tanggal pembayaran dividen $(\mathrm{t}=0)$, average abnormal return bernilai negatif dan signifikan pada level 5\% (sesuai dengan uji t, uji Crude Dependence Adjustment, 


\section{PERFORMANCE}

Jurnal Personalia, Financial, Operasional,

Marketing dau Sistem Informasi

Performance. Volume 27 Nomor 2 Tahun 2020, 23-38

Uji Patell, Uji Boehmer atau BMP test) dan level 10\% (sesuai Uji Kolari). Melalui hasil pengujian statistik Average Abnormal Return tersebut dapat dilihat bahwa uji t secara konsisten didukung oleh sebagian besar uji signifikansi lainnya. Hal ini mengimplikasikan adanya informasi negatif yang diperoleh oleh pemegang saham dikarenakan adanya dana keluar dari perusahaan untuk pembayaran dividen kepada pemegang saham yang memiliki hak dividen.

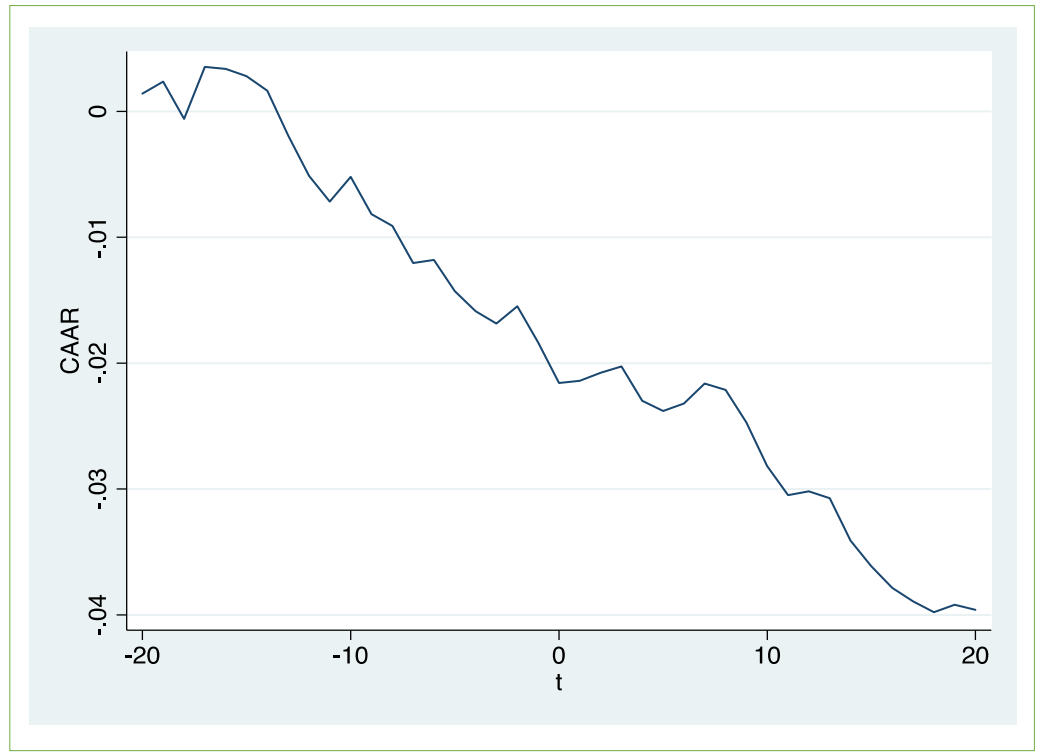

Gambar 3. Cumulative Average Abnormal Return di sekitar Peristiwa Pembayaran dividen

Tabel 4. Average Abnormal return (AAR) pada t-5 s.d. t+5 Pembayaran dividen

\begin{tabular}{|c|c|c|c|c|c|c|c|c|c|}
\hline $\mathrm{t}$ & AAR & t_test & CDA & Patell & Boehmer & Kolari & Corrado & Zivney & GenSign \\
\hline-5 & $-0,0017$ & & & & & & & & \\
\hline-4 & $-0,00296$ & $* *$ & * & $* *$ & $*$ & & & & \\
\hline-3 & $-0,00047$ & & & & & & & & \\
\hline-2 & 0,001662 & & & $*$ & & & & & \\
\hline-1 & $-0,00314$ & $* *$ & $* *$ & $* *$ & $* *$ & * & & & $* *$ \\
\hline 0 & $-0,00311$ & $* *$ & $* *$ & $* *$ & $* *$ & * & & & \\
\hline 1 & 2,67E-05 & & & & & & & & \\
\hline 2 & 0,000548 & & & & & & & & \\
\hline 3 & 0,000595 & & & & & & & & \\
\hline 4 & $-0,00326$ & $* *$ & $* *$ & * & & & & & * \\
\hline 5 & $-7 E-05$ & & & & & & & & \\
\hline
\end{tabular}

Tabel 5 menampilkan berbagai hasil uji statistik data untuk Cumulative Average Abnormal Return (CAAR) dengan 7 (tujuh) jendela peristiwa. Pada ketujuh jendela peristiwa, CAAR bernilai negatif dan di jendela peristiwa $[-5,0],[-1,0]$ dan $[-5,5]$ diperoleh hasil CAAR negatif secara signifikan dari Sebagian besar uji statistik, teruta, a uji t, CDA, Patell, Boehmer, dan Kolari. Dengan demikian berbagai hasil uji statistik ini mendukung hipotesis kedua bahwa terdapat reaksi pasar atas peristiwa pembayaran dividen, yaitu di sekitar tanggal payment-dividend. 
Performance. Volume 27 Nomor 2 Tahun 2020, 23-38

Tabel 5. Cumulative Average Abnormal Return(CAAR) di sekitar Pembayaran dividen

\begin{tabular}{cccccccccc}
\hline t & CAAR & t-test & CDA & Patell & Boehmer & Kolari & Corrado & Zivney & GenSign \\
\hline$[-5 ; 0]$ & $-0,00988$ & $* * *$ & $* *$ & $* * *$ & $* * *$ & $* *$ & & & $* *$ \\
{$[-3 ; 0]$} & $-0,0045$ & & & & & & & & \\
{$[-1 ; 0]$} & $-0,00637$ & $* * *$ & $* * *$ & $* * *$ & $* * *$ & $* *$ & $*$ & & \\
{$[0 ; 1]$} & $-0,00296$ & & & $*$ & & & & \\
{$[0 ; 3]$} & $-0,00195$ & & & & & & & \\
{$[0 ; 5]$} & $-0,00485$ & & & $*$ & & & & \\
{$[-5 ; 5]$} & $-0,0116$ & $* *$ & $* *$ & $* * *$ & $* * *$ & $* *$ & & & \\
\hline
\end{tabular}

KESIMPULAN

Penelitian Harrington dan Shrider (2007) menunjukkan bahwa pengujian statistik yang dibutuhkan untuk meyakinkan adanya abnormal return pada suatu peristiwa tidak cukup hanya dengan uji-t klasik karena adanya bias akibat volatilitas yang disebabkan oleh suatu peristiwa sehingga dibutuhkan metode uji statistik yang lebih robust untuk membuktikan bahwa abnormal return benar terjadi sebagai reaksi pasar atas sebuah peristiwa yang relevan, misalnya pada rangkaian peristiwa pembayaran dividen. Penelitian ini menunjukkan hasil dari berbagai uji statistik lain selain uji t, baik uji parametrik maupun nonparametrik. Berbagai uji statistik tersebut adalah Patell test of standardized residuals, Boehmer test of standardized residuals corrected for eventinduced changes in volatility, Brown and Warner's Crude Dependence Adjustment for Event Clustering, Kolari test of standardized residuals corrected for event-induced changes in volatility and cross-correlation, Corrado rank test dan Corrado and Zivney rank test corrected for eventinduced volatility of rankings.

Hasil Dari penelitian ini menunjukkan bahwa bahwa uji t secara konsisten menunjukkan adanya abnormal return pada tanggal cum-dividend dan tanggal pembayaran dividen. Hasil uji t ini didukung oleh berbagai uji lain yang disarankan pada penelitian Harrington dan Shrider (2007). Implikasinya, dapat dikatakan bajwa apa yang ditunjukkan oleh uji t, yang secara umum digunakan oleh para peneliti untuk menguji abnormal return pada sebuah peristiwa penting ,selaras dengan berbagai uji yang disarankan oleh literatur. Dengan demikian, terdapat indikasi yang cukup kuat bahwa memang terdapat abnormal return di sekitar tanggal cum-dividend dan pembayaran dividen. Dengan bukti empiris yang ditunjukkan pada penelitian ini, maka investor di pasar modal Indonesia masih dapat memanfaatkan rangkaian peristiwa pembayaran dividen untuk mendapatkan keuntungan, khususnya pada tanggal cum-dividend dan tanggal pembayaran dividen. Kemudian, penelitian selanjutnya dapat menguji reaksi pasar atas peristiwa lain, misalnya pada peristiwa merger dan akuisisi atau peristiwa pengumuman pemberian kredit atau pendanaan oleh bank dengan berbagai metode pengujian statistik yang digunakan pada penelitian ini untuk memvalidasi hasil penelitian terdahulu yang hanya menggunakan uji t.

\section{DAFTAR PUSTAKA}

Black, F., \& Scholes, M. (1974). The Effects of Dividend Yield and Dividend Policy on Common Stock Prices and Returns. Journal of Financial Economics, Vol.1(1): 1-22.

Boehmer, E, Jim Masumeci \& A.B. Poulsen. (1991). "Event-Study Methodology Under Conditions of Event-Induced Variance". Journal of Financial Economics. Vol 30(2): 253-272.

Brown, S. J \& J. B. Warner. (1980). "Measuring Security Price Performance". Journal of Financial Economics. Vol 8(3): 205-258.

Corrado, C. J. (1989). "A Nonparametric Test for Abnormal Secuity-Price Performance in Event Studies". Journal of Financial Economics. Vol 23(2): 385-395. 
Performance. Volume 27 Nomor 2 Tahun 2020, 23-38

Corrado, C. J \& T. L. Zivney. (1992). "The Specification and Power of the Sign Test in Event Study Hypothesis Tests Using Daily Stock Returns". Journal of Financial \& Quantitative Analysis. Vol 27(3): 465-478.

Cowan, A.R. (1992). "Nonparametric Event Study Tests". Review of Quantitative Finance and Accounting. Vol 2(4): 343-358.

Endri (2009). "Efek PengumumanKebijakanDividen Terhadap Return Saham yang Tergolong Jakarta Islamic Indexs". Ekuitas. Vol. 13 No. 4

Fama, E, Fisher L, Jensen, M \& Roll, R (1969). "The Adjustment of Stock Prices to New Information". International Economic Review. Vol. 10: 1-21

Fama, Eugene F (1970). "Efficient Capital Markets: A Review of Theory and Empirical Work". The Journal of Finance. Vol. 25(2): 383-417.

Harrington, Scott, E \& David G. Shrider (2007). "All Events induce Variance: Analyzing Abnormal returns When Effects Vary Across Firms". Journal of Financial and Quantitative Analysis. Vol. 42: $229-256$

Haryanto, Sugeng (2011). "Reaksi Investor Terhadap Pengumuman Dividen di Bursa Efek Indonesia". Jurnal Keuangan dan Perbankan. Vol. 15: 213-220

Kadapakkam, Palani-Rajan \& Valeria Martinez. (2008). "Ex Dividend Returns: The Mexican Puzzle". Journal of Banking \& Finance. Vol 32: 2453-2461

Kolari, J.W \& S. Pynnonen. (2010). "Event Study Testing with Cross-Sectional Correlation of Abnormal Returns". Review of Financial Studies. Vol 23(11): 3996-4025.

Kusno, John Iwan \& Fransisca Tharia Hartanto (2018). "Dampak Pengumuman Dividen Kas Terhadap Abnormal Return pada Indeks LQ-45". Jurnal Riset Akuntansi dan Keuangan. Vol. 6(3): 441-452

Koski, J.L., Scruggs, J.T.,(1998). "Who Trades around the Ex-Dividend Day? Evidence from NYSE Audit File Data". Financial Management. Vol 27: 58-72

Lavista, Eka \& Elok Sri Utami (2017). "Stock Price Reactions Around Cum-Dividend Date in Indonesia Stock Exchange". Journal of Accounting - Business \& Management. Vol 24 No 1: 6473.

Lestari, Ayu Retsi, Alfi Arif \& Bayu Wijayantini. (2018). "Relevansi Cum-Dividend Date dengan Perubahan Harga Saham pada Sektor Manufaktur di Bursa Efek Indonesia". Balance. Vol XV No2.

Miller, M.H \& Modigliani, F (1961). "Dividend policy, growth, and the valuation of shares". Journal of Finance. Vol. 56: 2111-2133

Mutiara KD, Fransisca A. (2020). "Dividend policy, growth, and the valuation of shares". Reaksi Pasar atas Pembayaran Dividend di Indonesia (Unpublished Thesis). Universitas Gadjah Mada, Indonesia.

Ngoc, Dinh Bao \& Nguyen Chi Cuong (2016). "Dividend Announcement and Ex Dividend Effects on Stock Return". International Journal of Economics and Finance. Vol 8 No 7.

Patell, J.M. (1976). "Corporate Forecasts of Earnings Per Share and Stock Price Behavior: Empirical Tests". Journal of Accounting Research. Vol 14(2): 246-276.

Raymond (2017). "Pengaruh Pengumuman Pembagian Dividen Terhadap Harga Saham Sebelum dan Sesudah Ex-Dividend Date pada Kelompok Industri Manufaktur dan Jasa yang Terdaftar di BEI". Jurnal Akuntansi. Vol. 5(2): 190-202. 